\title{
TECHNOLOGY INTEGRATED WITH METACOGNITIVE
} REGULATION APPROACH TO ENHANCE STUDENTS' MASTERY AND CREATING EFFECTIVE LEARNING IN MATHEMATICS

\section{Mohamad Ariffin Abu Bakar*}

School of Education, Faculty of Social Sciences and Humanities

Universiti Teknologi Malaysia

Malaysia

mohamadariffin6299@gmail.com

\section{Norulhuda Ismail}

School of Education, Faculty of Social Sciences and Humanities

Universiti Teknologi Malaysia

Malaysia

p-norulhuda@utm.my

*Corresponding author's Email: mohamadariffin6299@gmail.com

Peer-review under responsibility of 4th Asia International Multidisciplinary Conference 2020 Scientific Committee http://connectingasia.org/scientific-committee/ (C) 2020 Published by Readers Insight Publisher, lat 306 Savoy Residencia, Block 3 F11/1,44000 Islamabad. Pakistan, editor@readersinsight.net

This is an open access article under the CC BY-NC-ND license (http://creativecommons.org/licenses/by-nc-nd/4.0/). 


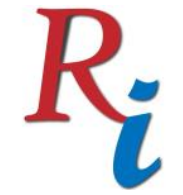

\section{Asia Proceedings of Social Sciences \\ (APSS) \\ www.readersinsight.net/APSS}

\section{A b s t r a c t}

Modules development is one of the necessities for producing learning interventions. Therefore, the existing study is an attempt to see the effectiveness of mathematical learning based on a metacognitive regulation approach with the technology integrated through modules, kits and interactive activities. The objective of this study was to look at the impact of using the Meta-Seller Tutoring module and mathematics learning kit on the metacognitive regulation skills and mastery of student mathematics concepts. Based on a quantitative approach using experimental design, the present study involved 159 students from three secondary schools in Pasir Gudang, Malaysia. The results show that the use of modules combined with technology and metacognitive regulation strategies has the greatest impact on the metacognitive regulation skills and students' mastery of mathematics concepts and significantly in shaping effective learning. The implications indicate that teachers can use the module as an intervention in mathematics learning.

\section{Rese a r ch H igh I ight s}

The needs of development of this module are due to the weak issue of mathematics achievement and teacher difficulty in choosing activities that can improve students' understanding. According to Tony Karnain et al (2014), Ibrahim \& Iksan (2017) and Abdullah, Rahman \& Hamzah (2017), the level of mastery in mathematics among students is still low and impedes the achievement of mathematics. Musso, Kyudt, Cascallar \& Dochy (2012) and Phi (2017) argued that, among the issues leading to poor learning in mathematics teaching, students' metacognitive regulation skills during learning are not well established. Subsequently, the final stage of the study was the testing of the modules to the target group to determine the effectiveness of the module. The purpose of this experimental design study is to determine the effectiveness of modules designed and developed based on metacognitive regulation strategies with the injection of several technology elements. The results show that this module is important in practising metacognitive skills and influencing students' mastery of mathematics concepts.

\section{Research Objectives}

The Meta-Seller Tutoring (MST) module has been developed as an intervention to the problem of weak of students mastery in mathematics concepts (Bakar \& Ismail, 2020). In fact, the purpose of this research was to assess the effectiveness and seeing the impact of using the module on students' metacognitive regulation skills and mastery of mathematics concepts. The research questions are, do the MST module and kit affect students' mastery of mathematics concepts compared to conventional learning?, do the MST module and kit influence students' metacognitive regulation skills? and, is there a significant relationship 


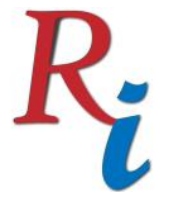

\section{Asia Proceedings of Social Sciences}

(APSS)

www.readersinsight.net/APSS

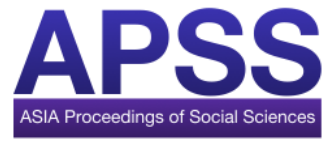

between metacognitive regulation skills and mastery of students' mathematics concepts after implementation of MST learning?

\section{Methodology}

159 students from three secondary schools were involved. Based on the experimental study method, the participant was divided into two groups, including experimental groups, which received treatment using MST module, while the control group adopted conventional learning. All groups enrolled in mathematics class by conducting with the same teacher and the same topic for a duration of 4 weeks. Until the beginning of the treatment session, both groups had completed a mastery test and responded to the metacognitive regulation questionnaire to assess the current level of mastery and metacognitive regulation skills. After the treatment session, both groups carried out a mastery test and answered to the post-test metacognitive regulation questionnaire to see progress in the treatment session. Data were analysed on the basis of descriptive and inferential statistics utilizing SPSS, version 23.

\section{Results}

Overall, the learning activities through the modules and kits have an impact and effect on the learning and mastery of students' mathematics concepts. The mastery scores of the experimental group showed a greater increase with the mean score ranging from 56.10 to 65.93, while the mean of control group just changed from 58.84 to 61.56 . There is a significant difference between pre and post scores for experiment group $(p=0.000)$, and there is no significant difference throughout the control group. The total of mean control group score recorded a rise from 2.72 for pre-test to 2.76 for the post-test, but the improvement for the experimental group showed a higher value of 2.63 in pre-test to 2.85 in post-test for the metacognitive regulation score. For the experiment groups, there was a significant difference between the pre and post metacognitive regulation scores $(p=0.002$ $<0.05)$, but not significant in the control group. There was a significant difference recorded ( $p$ $=0.014<0.05)$ for metacognitive regulation scores in post-test between groups but not significant for pre-test. The relationship of mastery score and the metacognitive regulation score of the experimental group in the post-test showed a significant correlation with a sufficient correlation $(r=0.301 ; p=0.007)$.

\section{Findings}

MST module has been developed by applying a metacognitive regulation strategy with integrated of technology. Such results have shown that the module and the integrated technology in their activities and learning kit can effectively influence students' mathematics 


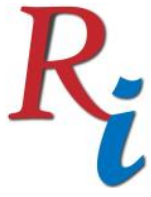

\section{Asia Proceedings of Social Sciences}

(APSS)

www.readersinsight.net/APSS

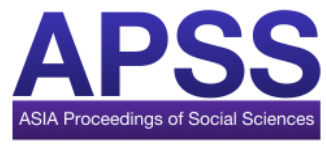

concepts. Through the module, students' mastery can be improved and the module is suitable for intervention in mathematics learning.

\section{References}

Abdullah, A.H., Rahman, S.N.S.A. \& Hamzah, M.H. (2017). Metacognitive Skills of Malaysian Students in Non-Routine Mathematical Problem Solving. Bolema, Rio Claro (SP), 31(57), 310-322.

Bakar, M.A.A. \& Ismail, N. (2020). Testing the Validity and Reliability of Metaseller Tutoring Module for the Purpose of Mathematics Learning Intervention. Universal Journal of Educational Research, 8(3A), 35-41. doi: 10.13189/ujer.2020.081405.

Ibrahim, N. H., \& Iksan, Z. (2017). Metacognitive Strategy and High-Level Thinking Skills In Teaching and Learning Process. Simposium Pendidikan Diperibadikan: Perspektif Resale-i-Nur, 131-139. 25-26 Jan. 2017, Akademi Kepimpinan Pendidikan Tinggi (AKEPT), UKM, Bangi, Malaysia.

Musso, M., Kyndt, E., Cascallar, E., Dochy, F. (2012). Predicting Mathematical Performance: The Effect of Cognitive Processes and Self-Regulation Factors. Education Research International, Volume 2012. doi:10.1155/2012/250719.

Phi, V.T. (2017). Developing Students Metacognitive Skills In Mathematics Classroom. Annals. Computer Science Series, 14(1).

Tony Karnain, Bakar, M.N., Siamakani, S.Y.M., Mohammadikia, H. \& Muhammad Candra, M. (2014). Exploring the Metacognitive Skills of Secondary School Students' Use during Problem Posing. Jurnal Teknologi (Social Sciences), 67(1), 27-32

Author's Biography

Mohamad Ariffin Abu Bakar is a student who is currently undertaking his master's in mathematics study program under School of Education, Faculty of Social Sciences and Humanities, Universiti Teknologi Malaysia, Johor, Malaysia.

Norulhuda Ismail is a senior lecturer in Sciences, Mathematics and Creative Multimedia Department in School of Education, Faculty of Social Sciences and Humanities, Universiti Teknologi Malaysia, Johor, Malaysia. 